\title{
DIGITĀLĀ SATURA NODOŠANA APMAIN̦Ā PRET PATĒRĒTĀJA PIEKRIŠANU PERSONAS DATU APSTRĀDEI
}

\section{PROVIDING DIGITAL CONTENT IN EXCHANGE FOR CONSUMER CONSENT TO PROCESSING OF PERSONAL DATA}

\author{
Zanda Dāvida, Mg. iur. \\ Latvijas Universitātes Juridiskās fakultātes doktorante
}

\begin{abstract}
Summary
In recent decades, the Internet and the development of digital technologies have promoted the appearance of new digital products. New business models have emerged, in which digital content or digital services are also provided, and in exchange for these, the consumer does not pay a fee but instead provides personal data to the trader. Different forms of such business models are used in a considerable part of the market. This issue was recognized by the EU legislator when drafting Directive 2019/770 on certain aspects of contracts for the supply of digital content and services. The author of the paper will analyse the implementation of Directive 2019/770 and its effects in the field of contract law in Latvia, in cases where the consumer does not pay a fee but provides personal data to the trader. The aim of the paper is to evaluate the implementation provisions and to identify potential gaps in the regulation in the analysed area, and, finally, to assess whether the goals of the Directive are achievable.
\end{abstract}

Atslēgvārdi: Direktīva 2019/770, personas dati, patērētāja piekrišana, Latvijas civiltiesības.

Keywords: Directive 2019/770, personal data, consumer consent, Latvian civil law.

\section{Ievads}

Pēdējās desmitgadēs internets un digitālo tehnologiiju sniegtās iespējas ir būtiski manījušas sabiedrību - gan mūs kā indivīdus, gan saimniecisko darbību. Šîs pārmainas noris lielā ātrumā un pārnacionālā mērogā, kas līdztekus ieguvumiem rada sarežğìtus tiesībpolitiskus jautājumus un ietekmē nacionālo valstu tiesību tradicionālās vērtības. Eiropas Savienības dalībvalstis saskaras ar līdzīgām problēmām, taču to rīcỉbā esošie valstiskie instrumenti ir ierobežoti, lai ḷautu tām efektīvi atrisināt visus jautājumus par šo pārmaiṇu procesu. Pētỉjumi apliecina, ka patērētāi katru gadu ietaupītu ap 11,7 biljoniem eiro, ja varētu tiešsaistes pirkumus veikt no visa Eiropas Savienības preču un pakalpojuma klāsta. 61\% patērētāju uzticas savas valsts tiešsaistes pārdevējam, bet tikai $38 \%$ uzticas citu ES valstu 
pārdevējiem. ${ }^{1}$ Redzot, ka nacionālajā līmenī digitālās tehnologijas netiek pilnvērtīgi izmantotas un problēmjautājumu risinājumi nav pietiekoši efektīvi, Eiropas Komisija izstrādāja un 2015. gada 6. maijā publicēja Eiropas Digitālā vienotā tirgus stratēgiju. ${ }^{2}$ Tās mērḳis bija radīt tādus tirgus apstākḷus, kas ḷauj patērētājiem un uzñēmumiem pilnvērtīgi izmantot interneta un digitālo tehnologiju sniegtās iespējas. Lai sasniegtu šo mērḳi, stratēgijā tika izvirzìti trīs veicamo darbību virzieni, kur viens no tiem paredzēja izstrādāt tādu normatīvo bāzi, kas veicinātu patērētāju labāku piekḷuvi digitālajām precēm un pakalpojumiem visā Eiropā. Lai likvidētu šḳēršlus pārrobežu darbībām tiešsaistē un veicinātu patērētāju iepirkšanos kopējā Eiropas Savienības telpā, tika uzsvērts, ka šim nolūkam ir steidzami jāmazina būtiskākās atš̌ķirības starp tiešsaistes un bezsaistes vidi. Šì iniciatīva rezultējās ar divu savstarpēji saistītu patērētāja pirkuma direktīvu - Eiropas Parlamenta un Padomes Direktīvas (ES) 2019/771³ (turpmāk - patērētāja pirkuma direktīva) un Eiropas Parlamenta un Padomes Direktīvas (ES) 2019/770 ${ }^{4}$ (turpmāk - digitālā satura direktīva) - pieņemšanu. Minētās direktīvas dalībvalstīm ir jāpārṇem līdz 2021. gada 1. jūlijam, bet to piemērošana ir jāsāk ar 2022. gada 1. janvāri. N̦emot vērā minēto, Latvijas Republikas Ekonomikas ministrija ir sagatavojusi likumprojektu "Grozījumi Patēētāju tiesību aizsardzības likumā" (turpmāk Likumprojekts). ${ }^{5}$ Lielākajai daḷai dalībvalstu, tai skaitā Latvijai, direktīvu pārṇemšana rada jaunus izaicinājumus. Proti, no vienas puses, ir aktualizējies jautājums, kā nodrošināt direktīvu atbilstošu un korektu pārṇemšanu nacionālajos normatīvajos aktos un, no otras puses, kā nodrošināt jaunā regulējuma sistēmisku atbilstību civiltiesībām, personas datu aizsardzības tiesībām un jau esošajam patērētāju tiesību aizsardzības regulējumam nacionālajā valstī.

N̦emot vērā raksta apjomu un darba autores interesi, pētījuma objekts ir sašaurināts līdz digitālā satura direktīvas piemērošanas jomai, kas ir regulēta direktīvas 3. panta 1. punkta 2. teikumā. Raksta mērķis ir noskaidrot digitālā satura nodošanas apmaiṇā pret patērētāja piekrišanu personas datu apstrādei darījuma fenomena spēju iekḷauties Latvijas civiltiesībās. Lai sasniegtu izvirzīto mērḳi, darbā ir izmantotas šādas zinātniski pētnieciskās metodes: gramatiskā, teleologiskā, sistemātiskā (izprotot normatīvo regulējumu un analizējot tiesību mijiedarbību), salīdzinošā (salīdzinot dažādos avotos paustos zinātnieku viedokḷus), analītiskā (analizējot dažādu veidu avotus), deduktīvā (no vispārīgiem secinājumiem konkretizējot to ietekmi uz konkrētiem faktiem) un induktīvā (no atsevišķām atziṇām pārejot uz vispārīgā apkopošanu).

Secinājumos tiek izvirzìta tēze, ka patērētāju datus juridiski nevar atzìt par maksāšanas līdzekli, tai pašā laikā nenoliedzot, ka tiem ir mantiska vērtība. Saimnieciskās darbības jeb biznesa modelis, kurā patērētājs apmaiṇā pret digitālo

\footnotetext{
${ }^{1}$ A Digital Single Market Strategy for Europe. 6 May 2015 Communication from the Commission to the European Parliament, the Council, the European Economic and Social Committee and the Committee of the Regions COM (2015) 192 final. Pieejams: https://eur-lex.europa.eu/legal-content/EN/TXT/HTML/ ?uri=CELEX:52015DC0192\&from=LV [aplūkots 07.03.2021.].

${ }^{2}$ Ibid.

${ }^{3}$ Eiropas Parlamenta un Padomes Direktīva (ES) 2019/771 (2019. gada 20. maijs) par atseviškiem preču pārdošanas līgumu aspektiem, ar kuru groza Regulu (ES) 2017/2394 un Direktivu 2009/22/EK un atcel Direktīvu 1999/44/EK. OV L 136, 22.05.2019.

${ }^{4}$ Eiropas Parlamenta un Padomes Direktīva (ES) 2019/770 (2019. gada 20. maijs) par dažiem digitālā satura un digitālo pakalpojumu piegādes līgumu aspektiem. OV L 136, 22.05.2019.

${ }^{5}$ Likumprojekts "Grozijumi Patērētāju tiesību aizsardzības likumä". Pieejams: http://tap.mk.gov.lv/lv/mk/ tap/?pid=40495464 [aplūkots 07.03.2021.].
} 
saturu dod piekrišanu apstrādāt savus datus, ir mūsdienu realitāte, kurai ir jārod atbilstošs regulējums. Eiropas komisija starp sešām galvenajām 2019.-2024. gada politiskajām prioritātēm ir izvirzijusi prioritāti "Digitālajam laikmetam gatava Eiropa". ${ }^{6}$ Tās mērķis ir nodrošināt nepieciešamos tiesiskos, ekonomiskos un tehnologiskos instrumentus, lai tehnologijas kalpo cilvēkiem un rada pievienoto vērtību viṇu ikdienas dzīvē. Lìdz ar to nākotnē būs interesanti vērot, kā attīstīsies patērētāju datu kā vērtības tiesiskā izpratne un kā tā tiesiski korelēs ar jauniem saimnieciskās darbības modeḷiem.

\section{Digitālā satura direktīvas piemērošanas joma kā jaunums Eiropas līgumtiesībās}

Digitālā satura direktīvas mērḳis ir panākt dažu digitālā satura piegādes līgumu un digitālo pakalpojumu aspektu saskaņošanu, ņemot par pamatu augstu patērētāju aizsardzības līmeni. Lìdz ar to šo direktīvu piemēro ikvienam līgumam, kura ietvaros pārdevējs piegādā vai apṇemas piegādāt patērētājam digitālo saturu (video datnes, audio datnes, fotogrāfijas, e-grāmatas) vai digitālo pakalpojumu (lietotnes, mākoṇkrātuves un straumēšanas pakalpojumi) un patērētājs maksā vai apṇemas maksāt cenu. Digitālā satura direktīva paredz vairākus direktīvas piemērošanas izṇēmumus. ${ }^{7}$ Piemēram, direktīvu nepiemēro digitālajam saturam vai digitālajiem pakalpojumiem, kuri ir ietverti precēs vai kuriem ir savstarpēja saikne ar precēm (šajā gadījumā tiek piemērota patērētāja pirkuma direktīva ${ }^{8}$ ), veselības aprūpes pakalpojumu sniegšanas, finanšu pakalpojumu, azartspēḷ pakalpojumu līgumiem u. c. Minētie izņēmumi ir uzskatāmi par klasiskiem izņēmuma gadījumiem patērētāju tiesību aizsardzības direktīvās, jo argumentēti no regulējuma piemērošanas kompetences tiek izslēgtas konkrētas jomas. Dzīvei, zinātnei, cilvēka prātam attīstoties un radot jaunas sociālās realitātes, cilvēks turpina postulēt arvien jaunas vajadzības un tiesības. ${ }^{9}$ Tādējādi līdztekus norādītajai piemērošanas jomai digitālā satura direktīvas 3. panta 1. punkta 2. teikums paredz ieviest normatīvo bāzi Latvijā un daudzās citās dalībvalstīs līdz šim neregulētam līgumtiesību fenomenam - patērētāja piekrišanai personas datu apstrādei apmaiṇā pret digitālā satura saņemšanu.

Digitalizācija ir veicinājusi ievērojamu skaitu jaunu un nebijušu ar digitālā satura piegādi saistītu saimnieciskās darbības model̦u rašanos. Patērētāji var izvēlēties piedāvājumus pēc viṇu pieprasījuma vai daḷēji pēc viṇu pieprasījuma, pasūtītu lejupielādi, straumēšanu, interneta apraidi, interaktīvo televīziju, elektronisko

\footnotetext{
${ }^{6} 6$ Commission priorities for 2019-24. Pieejams: https://ec.europa.eu/info/strategy/priorities-2019-2024_ en [aplūkots 07.03.2021.]; sk. arī: Political guidelines of the Next European Commission 2019-2024. Ursula von der Leyen, 16 July 2019. Pieejams: https://ec.europa.eu/info/sites/info/files/political-guidelines-next-commission_en_0.pdf [aplūkots 07.03.2021.].

7 Eiropas Parlamenta un Padomes Direktivva (ES) 2019/770 (2019. gada 20. maijs) par dažiem digitālā satura un digitālo pakalpojumu piegādes līgumu aspektiem. OV L 136, 22.05.2019., 3. apsvērums un 3. panta 1., 4. un 5. punkts.

8 Eiropas Parlamenta un Padomes Direktīva (ES) 2019/771 (2019. gada 20. maijs) par atseviškiem preču pārdošanas līgumu aspektiem, ar kuru groza Regulu (ES) 2017/2394 un Direktivu 2009/22/EK un atcel Direktīvu 1999/44/EK. OV L 136, 22.05.2019., 3. panta 3. punkts.

9 N̦ikona L. Brīvība un dažādība sabiedrībā jāuztver kā vērtība. Intervija ar Inetu Ziemeli. Latvijas Vēstnesis, 04.03.2021. Pieejams: https://vportals.lv/viedokli/325510-briviba-un-dazadiba-sabiedriba-jauztver-kavertiba-2021 [aplūkots 07.03.2021.].
} 
grāmatu, žurnālu un avīžu piegādes abonēšanu, tiešsaistes pārraides sociālajos medijos, mākoṇpakalpojumus, lietotnes, var veikt pirkumus pašās lietotnēs un daudzus citus pakalpojumus. Attiecīgi šiem pakalpojumiem tiek pielāgoti dažādi maksāšanas veidi, sākot ar klasisko jeb monetāro cenu līdz maksājumiem natūrā (īpaši reklāmām) vai personas datu izmantošanai. ${ }^{10}$ Atsaucoties uz Eiropas Digitālā vienotā tirgus stratēgiju, Katri Havu (Katri Havu) norādīja, ka patērētāju kā lietotāju datu izmantošana komerciāliem mērḳiem dod iespēju identificēt konkrētas jomas, kurām ir nepieciešama tūlītēja analìtiska izpēte un normatīvā regulējuma izstrādāšana. ${ }^{11}$ Eiropas likumdevējs ir izvēlējies Norberta Reiha (Norbert Reich) un Hansa Miklica (Hans W. Micklitz) piedāvāto digitālā satura līgumu regulējuma nodalīšanu no klasiskā patērētāju pirkuma regulējuma, t. i., patērētāju pirkuma Direktīvas 1999/4412, kuru tuvākajā laikā atcels jaunā patērētāja pirkuma direktīva. Tiesību zinātnieki regulējuma nodalǐšanas nepieciešamību pamato ar digitālā satura līguma hibrīdo raksturu, ${ }^{13}$ taču secināms, ka tieši regulējuma nodalǐšana ir l̦āvusi Eiropas likumdevējam spert drosmīgu soli, paplašinot digitālā satura direktīvas piemērošanas jomu un tā rezultātā aptverot līdz šim normatīvi neregulētas sociālās realitātes situācijas. Proti, paredzot direktīvas piemērošanu arī tādiem inovatīiviem saimnieciskās darbības modeliem kā tiem, kuros patērētājs par pakalpojumu nemaksā, bet apmaiṇā pret to sniedz savus datus.

Attiecībā uz digitālā satura direktīvas 3. panta 1. punkta 2. teikumā noteikto direktīvas piemērošanas jomu ir jāvērš uzmanība, ka regulējums ietver arī izṇēmumus. Direktīvu nepiemēro gadījumos, kad digitālā satura vai pakalpojuma sniedzējs vāc personas datus tikai un vienīgi, lai sniegtu digitālo saturu vai digitālo pakalpojumu vai izpildītu juridiskās prasības. Pamatā direktīvas piemērošana attieksies uz tiem gadījumiem, kad digitālā satura vai pakalpojuma sniedzējs patērētāja sniegtos datus izmantos komerciāliem mērḳiem, taču tas neizslēdz cita veida gadījumus, kas varētu nebūt tieši saistīti ar digitālā satura sniedzēja komerciālo nolūku. Neskatoties uz iepriekš minēto, digitālā satura direktīva satur svarīgu norādi par direktīvas attiecībām ar personas datu aizsardzības regulējumu. Eiropas Savienības tiesību aktos par personas datu aizsardzību ir paredzēts izsmel̦ošs personas datu likumīgas apstrādes juridisko pamatu saraksts. Tādējādi jebkāda personas datu apstrāde saistîbā ar līgumu, kas ir šìs direktīvas darbības jomā, ir likumīga tikai tad, ja tā atbilst Vispārīgās datu aizsardzības regulas ${ }^{14}$ noteikumiem par juridiskajiem pamatiem personas datu apstrādei. Kolīzijas gadījumā starp digitālā satura direktīvu un Eiropas Savienības tiesību aktiem personas datu aizsardzības jomā pēdējie ir pārāki. ${ }^{15}$ Likumprojekts šādu piebildi neietver, tomēr, lai novērstu tiesību normu piemērošanas neatbilstības, to būtu ieteicams paredzēt.

${ }^{10}$ Helberger N., Loos M. B. M., Guibault L., Mak Ch., Pessers L. Digital Content Contracts for Consumers. Journal of Consumer Policy, 2013, pp. 36, 37-57.

${ }^{11}$ Havu K. The EU digital single market from a consumer standpoint: How do promises meet means? Contemporary Readings in Law and Social Justice, 2017, Vol. 9 (2), pp. 146-183.

12 Eiropas Parlamenta un Padomes Direktivva (ES) 1999/44 (1999. gada 25. maijs) par dažādiem patēriņa preču pārdošanas aspektiem un saistītajām garantijām. OV L 171, 07.07.1999.

13 Micklitz H.-W., Reich N. Sale of Consumer Goods. In: Micklitz H.-W., Reich N., Rott P. EU consumer law, $2^{\text {nd }}$ ed. Antwerpen; Portland, Oregon: Intersentia, 2014, p. 97.

14 Eiropas Parlamenta un Padomes Regula (ES) 2016/679 (2016. gada 27. aprīlis) par fizisku personu aizsardzību attiecībā uz personas datu apstrādi un šādu datu brīvu apriti un ar ko atceḷ Direktīvu 95/46/EK (Vispārīgā datu aizsardzības regula). OV L 119/1, 27.04.2016.

15 Eiropas Parlamenta un Padomes Direktīva (ES) 2019/770 (2019. gada 20. maijs) par dažiem digitālā satura un digitālo pakalpojumu piegādes līgumu aspektiem. OV L 136, 22.05.2019., 37. apsvērums. 
Digitālā satura direktīvas 3. panta 1. punkta 2. teikumā norādītā piemērošanas joma dod iespēju patērētājiem izmantot tiesiskās aizsardzības līdzekḷus digitālā satura vai digitālā pakalpojuma neatbilstības vai nepiegādāšanas gadỉjumā arī līgumiem, kuru ietvaros digitālā satura piegādātājs sniedz vai apṇemas sniegt patērētājam digitālo saturu vai digitālo pakalpojumu, bet patērētājs sniedz vai apṇemas sniegt personas datus. Tādējādi arī uz šiem līgumiem attieksies direktīvā paredzētā tiesisko aizsardzības līdzekḷu izmantošana. Tieši šis regulējuma darbības jomas paplašināšanas mērḳis dod patērētājiem tiesības uz līgumiskiem tiesiskās aizsardzības līdzekḷiem arī tādos saimnieciskās darbības modeḷos, kur patērētāja dati tiek saṇemti apmaiṇā pret digitālā satura nodošanu. Raksta ierobežotā apjoma dēl padziļināti netiek vērtētas sekas, kas iestātos gadījumā, ja līgums tiek atcelts vai konstatēta neatbilstība līgumam un ja patērētājs sniedzis savus datus apmaiñā pret digitālo saturu. Lai izprastu jauno regulējumu un nodrošinātu tā korektu ieviešanu Latvijas tiesībās, svarīgi ir saprast, kas ir patērētāja dati digitālā satura direktīvas kontekstā.

\section{Patērētāju dati digitālā satura direktīvas kontekstā}

Arvien vairāk digitālo pakalpojumu veidi balstās uz personas datu apstrādi, tai skaitā vākšanu un izmantošanu: veselības un sporta ierīces, personīgās efektivitātes lietotnes, personīgie asistenti, meklēšanas programmas, sociālie mediji, gudrā televīzija un citas ar internetu savienotās ierīces. ${ }^{16}$ Globālajā digitālajā ekonomikā komersanti vāc un izmanto patērētāju personas datus dažādiem mērķiem, sākot ar patērētāja pasūtījuma izpildi un pakalpojumu uzlabošanu, autentifikācijas un krāpšanas atklāšanu un beidzot ar patērētāja izsekošanu un personalizētas reklāmas radīšanu un piedāvāšanu patērētājiem. Sociālā realitāte apliecina, ka "par brīvu" ir interneta pakalpojumu noklusētā cena. ${ }^{17}$ Personas dati ir valūta, kas ḷauj patērētājam piekḷūt "bez maksas" tiešsaistes pakalpojumiem. Līdz ar to mūsdienās vairs nav noslēpums, ka patērētāju dati ir degviela saimnieciskajai darbībai digitālajā vidē. Šādu saimnieciskās darbības modeli izmanto tādas starptautiski spēcīgas digitālās platformas kā Facebook, YouTube, Instagram u. c. Līdz ar to datu komerciālā vērtība var būt finansiāli l̦oti augsta, tomēr kas tad īsti ir patērētāja dati - komerciāla vērtība, nauda, naudas digitāls ekvivalents, prece, maksāšanas līdzeklis?

N̦emot vērā, ka digitālā satura direktīva pirmo reizi Eiropas Savienības normatīvā regulējuma līmenī mēgina atbildēt uz jautājumu minētajā aspektā, tā analīzi ir vērts sākt tieši ar direktīvu kā izejošo tiesību avotu. Likumprojekta anotācijā norādīts, ka Likumprojektā tiek nostiprināta jau praksē esoša pieeja - maksāt naudas summu vai vērtības digitālu ekvivalentu. Praksē ir sastopams, ka, piemēram, lai varētu lietot kādu sociālo mediju platformu, ir jāsniedz savi personas dati - vārds, vecums, elektroniskā pasta adrese u. c. Šādos gadijumos tiek uzskatīts, ka patērētājs ir iegādājies digitālu saturu vai digitālu pakalpojumu, šajā gadījumā piekḷuvi

${ }^{16}$ Helberger N., Borgesius F. Z., Reyna A. The Perfect Match? A Closer Look at the Relationship between EU Consumer Law and Data Protection Law. Common Market Law Review, 2017, Vol. 54 (5), pp. 1427-1466.

17 Hoofnagle Ch. J., Whittington J. Free: Accounting for the Costs of the Internet's Most Popular Price. UCLA law review, 2014, 607, pp. 606-670. 
sociālo mediju platformai, piemēram, Facebook, par vērtības digitālu ekvivalentu. ${ }^{18}$ Tādējādi Likumprojekta anotācija noteic, ka patērētāja dati ir maksājuma veids jeb naudas vērtības digitāls ekvivalents. Tieši tāds pats kā elektroniskie vaučeri vai e-kuponi, digitālā valūta, kas tiek lietota, lai digitālajā vienotajā tirgū samaksātu par dažādām precēm vai pakalpojumiem. Digitālā satura direktīvas 2. panta 7. punkts definē "cenu", saprotot ar to naudas summu vai vērtības digitālu ekvivalentu, kas jāsamaksā par digitālā satura vai digitālā pakalpojuma piegādi. ${ }^{19}$ Savukārt Likumprojekts pārṇem direktivas definējumu, paredzot tā iekḷaušanu Patērētāju tiesību aizsardzības likuma 1. panta 18. punktā: digitālā satura vai digitālā pakalpojuma cena - naudas summa vai vērtības digitāls ekvivalents, kas jāsamaksā par digitālā satura vai digitālā pakalpojuma piegādi. ${ }^{20}$ Analizējot digitālā satura direktīvu, īpaši tās 23.-25. apsvērumu, secināms, ka Likumprojekta anotācija nonāk pretrunā ar direktīvu. Proti, patērētāja dati nevar būt nauda vai naudas digitāls ekvivalents. Tādējādi dati nav atzīstami par cenu, neskatoties uz to, ka pat specializētajā zinātniskajā literatūrā, tai skaitā tiesību zinātniskajos avotos, autori patērētāju datus mēdz salīdzināt ar cenu vai dēvēt par cenu.

Digitālā satura direktīvā ir uzsvērts, ka personas datus nevar uzskatīt par preci, jo tiesības uz personas datu aizsardzību ir pamattiesības. ${ }^{21}$ Personas dati un patērētāju dati kā daḷa no tiem ir pamattiesību vērtība. Eiropas datu aizsardzības uzraugs norāda, ka personas dati nevar tikt pielīdzināti ne naudai, ne precei. Tos nevar ne monetizēt, ne atzìt par komercdarījuma priekšmetu pat gadījumā, ja datu subjekts vēlas būt šāda darījuma puse. Nevajadzētu veicināt patērētāju vēlmi tirgoties ar tā datiem. Patērētājs, kuram nav citu līdzekḷu kā vien viṇa dati, lai iegādātos kādu pakalpojumu, visticamāk, šādās attiecībās kḷūs par upuri. ${ }^{22}$ Neskatoties uz minēto, sociālā realitāte tomēr prasa regulēt arī šādas patērētāju un komersantu attiecības. Pašlaik patērētājam minētajos saimnieciskās darbības modeḷos nav tiesību uz līgumiskiem tiesiskās aizsardzības līdzekḷiem, lai gan patērētāji apmaiṇā pret digitālo saturu dod piekrišanu izmantot potenciāli mantisku vērtību - datus. Līdz ar to Eiropas likumdevējs ir izvēlējies vidusceḷu, no vienas puses, patērētāju datus neatzīstot par maksāšanas līdzekli vai preci un, no otras puses, juridiski ne vien atzīstot patērētāju datus par pamattiesību vērtību, bet arī piešķirot tiem mantiskas vērtības nozīmi.

N̦emot vērā minēto, ir nepieciešamas labot Likumprojekta anotācijas sadaḷu "Dati kā maksāšanas līdzeklis", norādot, ka 1) patērētāju dati nav cena, nauda vai naudas digitāls ekvivalents; 2) patērētāju dati nav prece. Vienlaikus secināms, ka, neskatoties uz to, ka Likumprojekta sadaḷas virsraksts "Dati kā maksāšanas līdzeklis" konceptuāli nav pretrunā ar iepriekš minēto, jo norāda uz salīdzinājumu, datu pielīdzināšana maksāšanas līdzeklim nav tālredzīga, līdz ar to virsraksts bùtu

18 Likumprojekta "Grozījumi Patērētāju tiesību aizsardzības likumā” sākotnējās ietekmes novērtējuma ziņojums (anotācija). Pieejams: https://em.gov.lv/lv/Ministrija/sabiedribas_lidzdaliba/diskusiju_dokumenti/ [aplūkots 07.03.2021.].

19 Eiropas Parlamenta un Padomes Direktīva (ES) 2019/770 (2019. gada 20. maijs) par dažiem digitālā satura un digitālo pakalpojumu piegādes līgumu aspektiem. OV L 136, 22.05.2019., 2. panta 7. punkts.

${ }^{20}$ Likumprojekts “Grozijumi Patērētāju tiesību aizsardzības likumā”. Pieejams: http://tap.mk.gov.lv/lv/mk/ tap/?pid=40495464 [aplūkots 07.03.2021.], 2. lpp.

21 Eiropas Parlamenta un Padomes Direktīva (ES) 2019/770 (2019. gada 20. maijs) par dažiem digitālā satura un digitālo pakalpojumu piegādes līgumu aspektiem. OV L 136, 22.05.2019., 24. apsvērums.

22 European Data Protection Supervision Opinion "On the Proposal for a Directive on certain aspects concerning contracts for the supply of digital content”, 4/2017, 2017. Pieejams: https://edps.europa.eu/sites/ edp/files/publication/17-03-14_opinion_digital_content_en.pdf [aplūkots 07.03.2021.]. 
jālabo. Proti, likumprojektu anotācija ir viens no galvenajiem avotiem, kur ieskatās tiesību piemērotāji, saskaroties ar tiesību normu tulkošanas grūtībām. Latvijas normatīvajā regulējumā ietvertā maksāšanas līdzekḷa tiesību institūta izpratne ir cieši saistīta ar naudu ${ }^{23}$ un tā piesaisti kādas valsts nacionālajai valūtai. Savukārt patērētāja dati ir līgumisks maiņas līdzeklis, lai saṇemtu pakalpojumu. Tādējādi Likumprojekta attiecīgās sadaḷas virsraksts būtu maināms uz "Patērētāja piekrišana datu apstrādei kā līgumisks maiṇas līdzeklis pakalpojuma saṇemšanai”.

N̦emot vērā minēto, secināms, ka patērētāju dati digitālā satura direktīvas kontekstā ir ieguvuši Latvijas tiesību sistēmā līdz šim nepazìtu tiesisko izpratni. Turpmāk tiks apskatīts jautājums par to lomu un vietu Latvijas civiltiesību sistēmā kopumā.

\section{Jaunā regulējuma saskaņošana ar Latvijas civiltiesību sistēmu}

Saskaṇā ar digitālā satura direktīvas 12. apsvērumu direktīva neietekmē valstu tiesību aktus par līgumu izstrādi, spēkā esamību, spēkā neesamību vai sekām vai digitālā satura vai digitālā pakalpojuma likumību. Direktīva nenosaka līguma par digitālā satura vai digitālā pakalpojuma sniegšanu juridisko būtību un neregulē jautājumu par to, vai līgums par digitālā satura vai digitālā pakalpojuma sniegšanu ir uzskatāms, piemēram, par pirkuma, pakalpojumu, nomas vai sui generis līgumu. N̦emot vērā katras dalībvalsts tiesību sistēmas īpatnības, Eiropas likumdevējs minēto jautājuma noregulējumu ir atstājis valstu tiesību aktu kompetencē. Džoanna Hokstra (Johanna Hoekstra) un Aisema Dikere-Vanberga (Aysem Diker-Vanberg) norāda, ka digitālā satura direktīvas noteikumi nav pārdomāti, nav ilgtspējīgi un ir tuvredzīgi, jo nav izmantota iespēja noteikt digitālā satura un digitālā pakalpojuma sniegšanas līgumisko tiesību vienotu regulējumu. Dalībvalstīm joprojām ir atstāts pietiekami daudz brīvības, lai izveidotu vai saglabātu atšķirīgu regulējumu. ${ }^{24}$ Eiropas likumdevējs ir apzināti izvairījies digitālā satura direktīvā noteikt speciālo līgumu juridisko klasifikāciju (piemēram, paredzot, ka tas ir pirkuma līgums vai pakalpojuma sniegšanas līgums), bet paplašinājis direktīvas darbības jomu visiem patērētāju līgumiem, kas tiek slēgti par digitālā satura vai digitālā pakalpojuma sniegšanu. ${ }^{25} \mathrm{Li} d z$ ar to nav pārsteigums, ka tik plašs speciālo līgumu izpratnes tvērums neiekḷaujas daudzu nacionālo valstu tradicionālajās civiltiesību sistēmās un nekvalificējas kā tāda līguma veids, kas valstī jau zināms, piemēram, kā pirkuma līgums vai piegādes līgums.

Latvijas Universitātes 79. starptautiskās zinātniskās konferences plenārsēdē tiesību zinātṇu doktors Jānis Kārliṇš norādīja, ka uz līgumiem, kuru objekts ir digitālais saturs, pašlaik nav pilnvērtīgi attiecināmi Civillikumā paredzētie vispārējie atsavināšanas līgumu, piemēram, pirkuma līguma, maiņas līguma, dāvinājuma līguma, noteikumi. Proti, digitālais saturs nav ne k̦ermeniska, ne bezķermeniska lieta, līdz ar to uz digitālo saturu nevar tikt īstenota īpašuma tiesība. Tieši ìpašuma tiesības pārejas iespējamība ir atsavināšanas līgumus vienojošā pazīme. Lai risinātu šo situāciju, tika ieskicēti divi alternatīvi varianti: 1) papildināt patērētāju

${ }^{23}$ Piemēram, sk.: Kredītiestāžu likums: LV likums. Pienememts 05.10.1995. [16.02.2021. red.].

${ }^{24}$ Hoekstra, J., Diker-Vanberg, A. The proposed directive for the supply of digital content: is it fit for purpose? International Review of Law, Computers \& Technology, 2019, Vol. 33 (1), pp. 100-117.

25 Schulze, Staudenmayer. EU Digital Law. Article-by-Artlice Commentary. Germany: Nomos Verlagsgesellschaft, Baden-Baden, 2020, p. 7. 
tiesību aizsardzības likumu ar atrunu par Civillikumā paredzēto atsavinājuma līgumu regulējuma piemērošanu līgumiem, kuru objekts ir digitāls saturs, vai 2) iekḷaut norādi par digitālā satura pirkšanas iespējamību Civillikuma 2002. pantā. ${ }^{26}$

Patērētāju datu loma digitālā satura direktīvā, paredzot, ka tie var būt maiṇas līdzeklis digitālā satura saṇemšanai, tiesībjautājumu par digitālā satura līguma juridiskās būtības identificēšanu padara vēl komplicētāku. Pašlaik līgums (kura ietvaros digitālā satura vai digitālā pakalpojuma sniedzējs sniedz vai apṇemas sniegt patērētājam digitālo saturu vai digitālo pakalpojumu un patērētājs sniedz vai apṇemas sniegt pretī tam personas datus vai piekrišanu apstrādāt personas datus) neatbilst nevienam no Civillikumā regulētajiem atsavinājuma līguma veidiem, jo ne tikai trūkst īpašuma tiesību pārejas iespējamības (nav lietas), bet arī netiek izpildīts nosacījums par maksu/cenu, kas ir obligāta sastāvdaḷa lielākajai daḷai atsavinājuma līgumu veidu (izṇēmums ir maiṇas līgums; savukārt uztura līgums uz šo gadījumu neattiecas, tāpēc rakstā netiek apskatīts). Maiṇas līguma (Civillikuma 2091. pants) regulējuma piemērošana būtu vistuvākā norādìtā līguma juridiskajai būtībai, tomēr Civillikuma 2091. panta otrajā teikumā atrunātais maiņas līguma priekšmets nel̦auj mainīties ar personas datiem un digitālo saturu. Šis direktīvas galvenais jaunums par patērētāju datu lomu līgumtiesībās kontekstā ar digitālo ekonomiku būtiski ietekmēs Eiropas līgumtiesību attīstību. ${ }^{27}$ Pašlaik Latvijas tiesību sistēmā iepriekš minēto līgumu var kvalificēt kā sui generis jeb speciālo līgumu, kas neiekḷaujas Latvijas Civiltiesību sistēmas līgumu kvalifikācijā, līdz ar to paliek ārpus Civillikuma regulējuma. Pašlaik Likumprojektā būtu atbalstāms tiesību zinātṇu doktora Jāṇa Kārkliṇa ierosinājums. Proti, papildināt Patērētāju tiesību aizsardzības likumu ar atrunu par Civillikumā paredzēto atsavinājuma līgumu regulējuma piemērošanu līgumiem, kuru objekts ir digitāls saturs, ${ }^{28}$ piebilstot, kas tas tiek piemērots arī tajos gadījumos, kad patērētājs apmaiṇā pret digitālo saturu vai digitālo pakalpojumu sniedz savus datus vai dod piekrišanu savu datu apstrādei saskaṇā ar jaunā Patērētāju tiesību aizsardzības likuma $2 .{ }^{1}$ panta ceturto daḷu (Likumprojekta 2. punktu). Lai gan secināms, ka ilgtspējīga regulējuma izstrādei būtu ieteicams uzsākt diskusiju par Civillikuma 13. nodaḷas "Prasījumi no atsavinājuma līgumiem” modernizāciju kopsakarā ar digitālās ekonomikas attīstības sociālo realitāti, jo digitālā satura kā līguma objekta datu kā līgumiska maiņas līdzekḷa regulējums ir aktuāls arī komersantu jeb $B 2 B$ attiecībās. Proti, nebūtu pamatoti no tiesiskās aizsardzības izslēgt komersantus un digitālā satura direktīvas noteikumi būtu jāattiecina arī uz $B 2 B$ attiecībām.

${ }^{26}$ Jāṇa Kārkliṇa priekšlasījums "Pirkuma līguma objekta izpratne jauno patērētāju pirkuma direktīvu gaismā”. Latvijas Universitātes 79. starptautiskās zinātniskās konferences plenārsēde “Tiesības un tiesiska vide mainīgos apstākḷos”. Rīga, 21.02.2021. Programma pieejama: https://www.jf.lu.lv/fileadmin/user_upload/ LU.LV/Apaksvietnes/Fakultates/www.jf.lu.lv/zinas/2021/79konf/Plenarsede_JF_LU_79konference__1_. pdf [aplūkots 07.03.2021.].

27 Schulze, Staudenmayer. EU Digital Law. Article-by-Artlice Commentary. Germany: Nomos Verlagsgesellschaft, Baden-Baden, 2020, p. 7.

28 Jāṇa Kārkliṇa priekšlasījums "Pirkuma līguma objekta izpratne jauno patērētāju pirkuma direktīvu gaismā”. Latvijas Universitātes 79. starptautiskās zinātniskās konferences plenārsēde “Tiesības un tiesiska vide mainīgos apstākḷos”. Rīga, 21.02.2021. Programma pieejama: https://www.jf.lu.lv/fileadmin/user_upload/ LU.LV/Apaksvietnes/Fakultates/www.jf.lu.lv/zinas/2021/79konf/Plenarsede_JF_LU_79konference__1_. pdf [aplūkots 07.03.2021.]. 


\section{Kopsavilkums}

1. Sociālās realitātes radītās jaunās vajadzības ir rosinājušas Eiropas likumdevēju iniciēt tiesību normatīvās bāzes radīšanu Latvijā un daudzās citās Eiropas Savienības dalībvalstīs līdz šim neregulētam līgumtiesību fenomenam - līgumam, kurā tiek sniegts digitālais saturs apmaiṇā pret patērētāja datiem vai patērētāja piekrišanu datu apstrādei.

2. Digitālā satura direktīva satur svarīgas norādes par direktīvas attiecībām ar personas datu aizsardzības regulējumu. Proti, kolīzijas gadījumā starp digitālā satura direktivu un Eiropas Savienības tiesību aktiem personas datu aizsardzības jomā pēdējie ir pārāki. Likumprojekts šādu piebildi neietver, tomēr, lai novērstu tiesību normu piemērošanas neatbilstības, to būtu ieteicams paredzēt. Vienlaikus Likumprojektā ieteicams iekḷaut norādi, ka patērētāja izmantotie patērētāju tiesību aizsardzības līdzekḷi neietekmē patērētāja kā datu subjekta tiesības vienlaicīgi izmantot arī personas datu tiesību aizsardzỉbas regulējošajos normatīvajos aktos noteiktos tiesību aizsardzības līdzekḷus, ìpaši Regulā 2016/679 paredzētās tiesības. Piemēram, patērētāja tiesības atcelt līgumu neskar patērētāja kā datu subjekta tiesības uz datu dzēšanu, datu pārnesamību un piekrišanas atsaukšanu attiecībā uz personas datu apstrādi.

3. Patērētāja dati nevar būt nauda, naudas digitāls ekvivalents vai maksāšanas līdzeklis. Līdz ar to Likumprojekta anotācija nonāk pretrunā ar direktīvu. Vienlaikus dati nav prece, jo dati ir pamattiesību vērtība, lai gan tiem ir mantiskas vērtības pazīmes. Patēētāja piekrišana datu apstrādei vai patērētāja sniegtie dati ir jāvērtē kā līgumisku maiṇas līdzekli pakalpojuma saṇemšanai.

4. Pašlaik Latvijas tiesību sistēmā iepriekš minēto līgumu var kvalificèt kā sui generis jeb speciālo līgumu, kas neiekḷaujas Latvijas Civiltiesību sistēmas līgumu kvalifikācijā, līdz ar to paliek ārpus Civillikuma regulējuma. Likumprojektā atbalstāms būtu ierosinājums - papildināt Patērētāju tiesību aizsardzības likumu ar atrunu par Civillikumā paredzèto atsavinājuma līgumu regulējuma piemērošanu līgumiem, kuru objekts ir digitāls saturs, piebilstot, kas tas tiek piemērots arī tajos gadījumos, kad patērētājs apmaiṇā pret digitālo saturu vai digitālo pakalpojumu sniedz savus datus vai dod piekrišanu savu datu apstrādei saskaṇā ar jaunā Patērētāju tiesību aizsardzības likuma 2. ${ }^{1}$ panta ceturto dalı (Likumprojekta 2. punktu).

5. Vienlaikus ilgtspējīga regulējuma izstrādei būtu ieteicams uzsākt diskusiju par Civillikuma 13. nodaḷas "Prasījumi no atsavinājuma līgumiem" modernizāciju kopsakarā ar digitālās ekonomikas attīstības sociālo realitāti, jo digitālā satura kā līguma objekta datu kā līgumiska maiṇas līdzekḷa regulējums ir aktuāls arī komersantu jeb $B 2 B$ attiecībās.

Pētijumu atbalsta Latvijas Zinātnes padomes (LZP) Fundamentālo un lietišķo pētījumu projekts (FLPP) "Patērētāju aizsardzības stiprināšana digitālajā un datu laikmetā: jauno patērētāja pirkuma direktīvu ieviešana Latvijas tiesību sistēmā”.

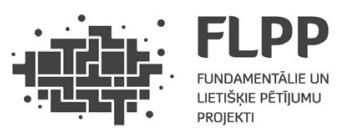

